\title{
Immobilization of $\mathrm{Cd}, \mathrm{Zn}$, and $\mathrm{Pb}$ from Soil Treated by Limestone with Variation of pH Using a Column Test
}

\author{
Sung-Wook Yun ${ }^{1}$ and Chan Yu ${ }^{1,2}$ \\ ${ }^{1}$ Institute of Agriculture \& Life Science, Gyeongsang National University, 900 Gazwa, Jinju, Gyeongnam 660-701, Republic of Korea \\ ${ }^{2}$ Department of Agricultural Engineering, Gyeongsang National University, 900 Gazwa, Jinju, Gyeongnam 660-701, Republic of Korea \\ Correspondence should be addressed to Chan Yu; chanyu@gnu.ac.kr
}

Received 14 January 2015; Revised 11 March 2015; Accepted 11 March 2015

Academic Editor: Chengshuai Liu

Copyright (c) 2015 S.-W. Yun and C. Yu. This is an open access article distributed under the Creative Commons Attribution License, which permits unrestricted use, distribution, and reproduction in any medium, provided the original work is properly cited.

\begin{abstract}
Decades of mining in South Korea have resulted in the contamination of large amounts of soil by metals. The most feasible approach to site restoration requires the use of a stabilization agent to reduce metal mobility. This study examined the leaching characteristics of limestone used as a stabilization agent when subjected to solutions of differing $\mathrm{pH}$. In a laboratory-scale column test, solutions with $\mathrm{pH}$ values of 3.5, 4.6, and 5.6, representing acidic to nonacidic rainfall, were applied to soil mixed with limestone. Test results indicate that metal components can be released with the addition of acidic solutions, even if the soil is highly alkaline. Cd and $\mathrm{Zn}$, in particular, exhibited abrupt or continuous leaching when exposed to acid solutions, indicating the potential for contamination of water systems as metal-laden soils are exposed to the slightly acidic rainfall typical of South Korea. Treatment using stabilization agents such as limestone may reduce leaching of metals from the contaminated soil. Stabilizing metal-contaminated farmland is an economical and feasible way to reduce pollutants around abandoned metal mines.
\end{abstract}

\section{Introduction}

Contamination by mining activities is one of the most serious causes of soil quality degradation [1]. About 1,104 metal mines have been documented in South Korea, and 1,069 of those (97\%) were abandoned after closure [2]. The tailings and wastes from these abandoned metal mines (AMMs) have significantly polluted nearby farmlands [3], and the resulting metal accumulation in crops poses a serious environmental threat to human health $[4,5]$, since neither are metals removed from the soil nor do their contents decrease [6]. The general approach for the remediation of metal-contaminated areas, therefore, is to excavate the contaminated soil and reclaim the land with clean soil. This method, however, not only is costly but also can lead to secondary contamination. It is also known to be destructive to the ecosystem [7-9].

Stabilization, an in situ technique, uses a stabilization agent to reduce the mobility and bioavailability of metals and is considered to be both economical and efficient $[3,8]$. Many studies have examined different stabilization agents and their mechanisms for reducing the mobility and bioavailability of metals in soil. According to Kumpiene et al. [10] and Ruttens et al. [6], it could be accomplished by increasing the $\mathrm{pH}$ of the soil, and alkaline materials are the most widely used to stabilize metal-contaminated soil. However, the durability of this method has not been proven, and treated areas require regular monitoring [11]. Still, until a more economical and effective remediation technique is developed, stabilization remains the most feasible alternative for the remediation of metal-polluted soils.

In South Korea, national environmental regulations stipulate the total content of metal in the soil, and therefore, it is not easy to set a remediation goal or to evaluate the results of stabilization. However, if polluted areas are left as they are, contamination may spread to the surrounding environment via rainfall or wind. Normal rain is slightly acidic with a $\mathrm{pH}=5.6$ and could accelerate the mobility of metals, whose solubility increases under weakly acidic conditions. Additionally, incidences of acid rain are expected to increase in severity as smog-laden air masses from China move into South Korea.

Further, in South Korea, the great majority of soils near AMMs are contaminated with $\mathrm{Zn}, \mathrm{Cd}$, and $\mathrm{Pb}$ [12]. In most cases, these components are distributed in contaminated 
TABLE 1: $\mathrm{pH}$ and XRF analysis results of the soil amendment used in this study.

\begin{tabular}{lcccccccc}
\hline \multirow{2}{*}{ Amendment } & \multirow{2}{*}{$\mathrm{pH}$} & $\mathrm{SiO}_{2}$ & $\mathrm{Fe}_{2} \mathrm{O}_{3}$ & $\mathrm{Al}_{2} \mathrm{O}_{3}$ & $\mathrm{CaO}$ & $\mathrm{MgO}$ & $\mathrm{MnO}^{1}$ analysis (\%) & $\mathrm{P}_{2} \mathrm{O}_{5}$ \\
\hline Limestone & 9.60 & 12.7 & 2.89 & 3.24 & 62.7 & 14.9 & 0.52 & 0.06 \\
\hline 1 r & & &
\end{tabular}

${ }^{1} \mathrm{X}$-ray fluorescence spectrometer.

soil in the form of various composites; the cases of singlecomponent contamination are extremely rare. Therefore, the applicability of a stabilization method should be examined with respect to $\mathrm{Cd}, \mathrm{Zn}$, and $\mathrm{Pb}$, without limiting to a specific single component.

This study investigates the long-term performance of stabilization with variation of $\mathrm{pH}$. Limestone was applied as a stabilization agent in a laboratory-scale column test, and the leaching characteristic of the metal components, that is, $\mathrm{Cd}$, $\mathrm{Zn}$, and $\mathrm{Pb}$, in the soil sample was observed and compared to the results of the control soil sample.

\section{Materials and Methods}

2.1. Soil Sampling. A representative soil sample was collected from farmland near Seosung Mine, located in Jigok, Seosan City, Chungnam Province, South Korea. Interviews with residents around the abandoned mine site indicated that tailings from the mine had been used periodically to replace the topsoil of farmlands. The farmlands have been left fallow because of metal contamination from mining activity. The soil was sampled using a shovel according to the Standard Method for Soil Analysis [13]. The sampled soil was transported to the laboratory, spread on a pan at a uniform thickness, and air-dried for a week. The specimen was sieved with a $2 \mathrm{~mm}$ sieve for physicochemical and metal analyses and with a $9.54 \mathrm{~mm}$ sieve for the column test.

2.2. Stabilization Agent. In this study, limestone $(<2 \mathrm{~mm})$ was used as the stabilization agent. In South Korea, limestone has been used as a stabilization agent for a long time because it is abundant and inexpensive. Calcareous materials increase soil $\mathrm{pH}$ and thus induce an increase in the soil's negative charge, which in turn induces the cationic metals to be adsorbed and precipitated onto the soil surface [14]. The technical manual of Korea Mine Reclamation Corp. states that both agents should be crushed to a particle size of less than and equal to $2 \mathrm{~mm}$ [15]. Table 1 shows the results of the $\mathrm{pH}$ and XRF analyses for the limestone used.

2.3. Procedure of Laboratory-Scale Column Test. Acrylic columns manufactured for the experiments had a thickness, inner diameter, and height of $0.5,10$, and $80 \mathrm{~cm}$, respectively, as shown in Figure 1. Two gate valves were installed at the top and bottom of each column to control irrigation and drainage. A $5 \mathrm{~cm}$ thick sand filtration layer was placed beneath the contaminated soil layer. Standard sand of Korean standard (KS L IOS 679), which had been sterilized for $30 \mathrm{~min}$ in an autoclave (KT4422, Kastech, Korea) at $121^{\circ} \mathrm{C}$, was used as the filter layer. Limestone was mixed with the
TABLE 2: Physical properties of the untreated and treated soils in the soil columns.

\begin{tabular}{lccc}
\hline Amendment & Void ratio & $\begin{array}{c}\text { Dry unit weight } \\
\left(\mathrm{g} / \mathrm{cm}^{3}\right)\end{array}$ & $\begin{array}{c}\text { Pore volume } \\
(\mathrm{mL})\end{array}$ \\
\hline Untreated control & 0.76 & 1.49 & 2,026 \\
Limestone treated & 0.73 & 1.51 & 1,988 \\
\hline
\end{tabular}

contaminated soil using a 5\% mixing ratio $(\mathrm{w} / \mathrm{w}$, based on dried weight), which is a general design value of the Mireco [15] manual. The control column was filled with contaminated soil only (see also Figure 1). Five contaminated or treated soil layers were compacted by 15 blows from a $20 \mathrm{~cm}$ height using a $2.38 \mathrm{~kg}$ rammer to increase in situ density. Table 2 shows the physical characteristics of the soil samples treated in the column.

Acidic solution was applied to the top of columns and maintained at a constant depth of $6 \mathrm{~cm}$ during the test period. Leachate collected from the bottom of columns at 1 pore volume (PV) intervals. $1 \mathrm{PV}$ corresponds to approximately $255 \mathrm{~mm}$ of rainfall; as the annual precipitation in South Korea is approximately $1,800 \mathrm{~mm}, 30 \mathrm{PV}$ corresponds to the precipitation of approximately 4 and a quarter years. The solution for the test was made by mixing $\mathrm{H}_{2} \mathrm{SO}_{4}$ and $\mathrm{HNO}_{3}(3: 1$ mole ratio) and diluting with distilled water to adjust the $\mathrm{pH}$. The $\mathrm{pH}$ levels of the solutions were chosen to mimic the $\mathrm{pH}$ values of normal rainfall (5.6) and the average and minimum $\mathrm{pH}$ values in South Korea during 2006 (4.8 and 3.6, resp.) based on data from the Korea Ministry of Environment [16]. The different solutions were consecutively introduced into the soil column at $10 \mathrm{PV}$ intervals. The entire leachate volume (30 PV) was collected from the columns. Before leaching, the control and treated soils in the columns were adjusted to $70 \%$ of field capacity moisture content and incubated for 2 days at room temperature. Columns were allowed to drain for $24 \mathrm{hr}$ before next acidic solution was applied.

2.4. Quality Analysis of Soil and Leachate. The physicochemical soil characteristics were analyzed according to NIST [17]. The $\mathrm{pH}$ (soil $<2 \mathrm{~mm}$ ) was measured using a $\mathrm{pH}$ and $\mathrm{EC}$ meter (Orion 550A, Thermo) at a 1:5 soil/distilled water ratio. The available phosphate (soil $<2 \mathrm{~mm}$ ) was measured via the Lancaster method using a spectrophotometer (UV1650 PC, Shimadzu, Japan). The exchangeable cations (soil < $2 \mathrm{~mm}$ ) were extracted using $1 \mathrm{M} \mathrm{NH}_{4} \mathrm{OAc}(\mathrm{pH} \mathrm{7)}$ and were measured using an inductively coupled plasma spectrometer (ICP/OES, Optima 5300DV, Perkin Elmer). The soil texture was measured by the hydrometer and sieve method.

The metal contents of the soil $(<0.15 \mathrm{~mm})$ were measured via aqua regia digestion $\left(3: 1, \mathrm{v} / \mathrm{v}, \mathrm{HCl}+\mathrm{HNO}_{3}\right)$ using an 


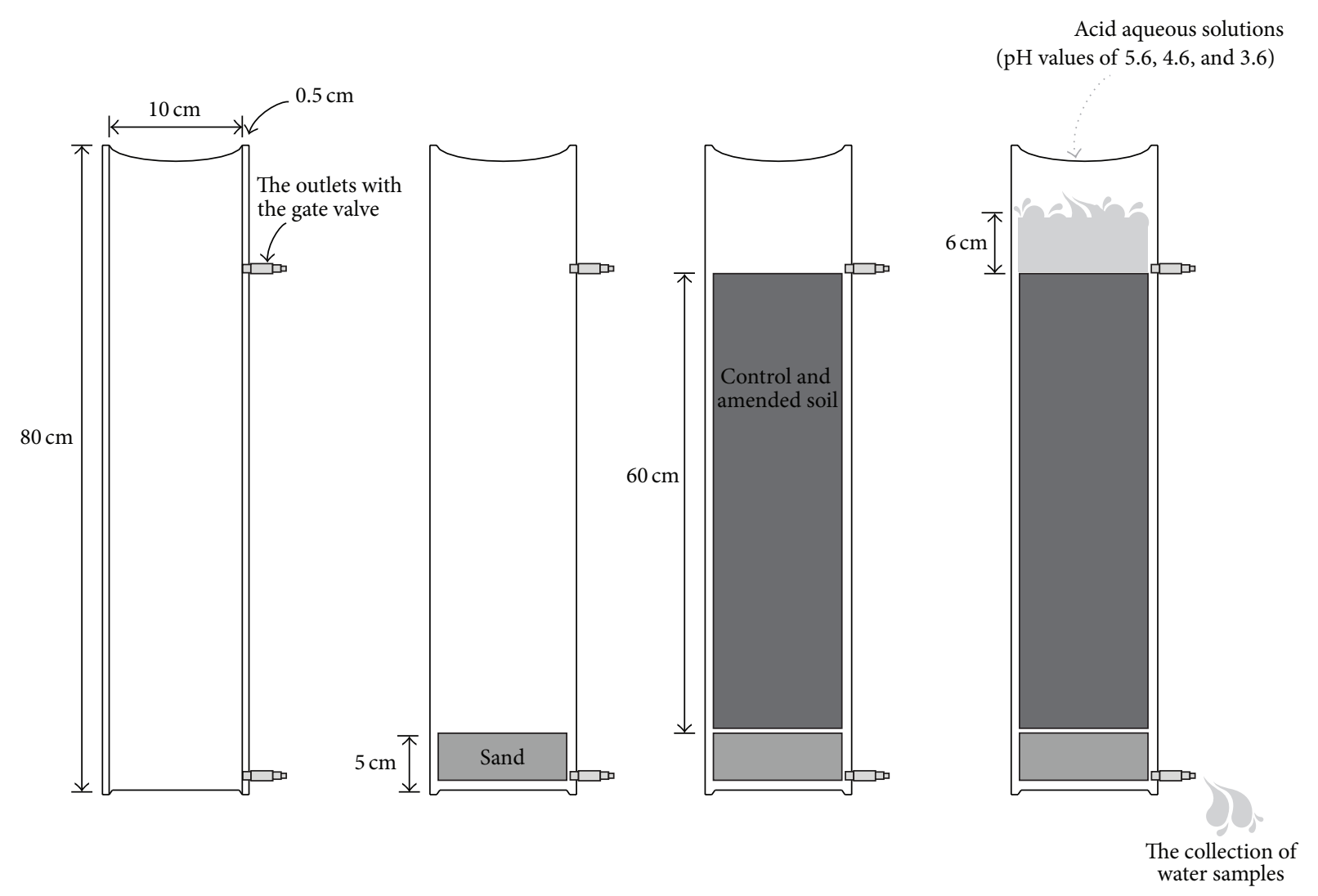

FIGURE 1: Diagram of the laboratory-scale column test for rainfall acidity simulation.

ICP/OES (Optima 5300DV, Perkin Elmer, USA), according to the Standard Method for Soil Analysis [13].

To investigate the fraction of metals in the soil $(<0.15 \mathrm{~mm})$, sequential extraction was performed using a modified BCR procedure. Four operationally defined fractions are acid soluble fraction (F1, soluble and exchangeable fraction and bound to carbonates, $0.11 \mathrm{M} \mathrm{CH} \mathrm{CHOH}_{3} \mathrm{CO}$, for $16 \mathrm{~h}$ ), reducible fraction (F2, bound to $\mathrm{Fe} / \mathrm{Mn}$ oxides, $0.5 \mathrm{M}$ $\mathrm{NH}_{2} \mathrm{OH} \cdot \mathrm{HCl}, \mathrm{pH} 2$, for $16 \mathrm{~h}$ ), oxidizable fraction (F3, bound to organic matter and sulfides, $30 \% \mathrm{H}_{2} \mathrm{O}_{2}$ acidified with $\mathrm{HNO}_{3}$ to $\mathrm{pH} 2$ at $85^{\circ} \mathrm{C}$ for $2 \mathrm{~h}$ and then followed by the extraction with $1 \mathrm{M} \mathrm{CH}_{3} \mathrm{COONH}_{4}, \mathrm{pH} 2-3$, for $16 \mathrm{~h}$ ), and residual fraction (aqua regia digestion). At the end of each sequential extraction step, before injecting the extraction solution of the next step, the sample was washed with distilled water to prevent residual components causing error. In addition, the sample was passed through a centrifugal separator to prevent any loss of the sample when effluent was collected. The metal components of all collected extracts were measured by ICP-OES (Optima 5300DV, Perkin Elmer, USA).

The leachate quality collected was analyzed using the pretreatment and analysis procedure according to the Standard Method of Water Analysis [18]. The $\mathrm{pH}$ and $\mathrm{EC}$ values were measured using a $\mathrm{pH}$ and EC meter (Orion 550A, Thermo, Japan), and the $\mathrm{Cd}, \mathrm{Pb}$, and $\mathrm{Zn}$ contents were measured using an ICP/MS (ELAN DRC II, Perkin Elmer, USA).
2.5. Data Analysis. The Pearson correlation of the physicochemical soil characteristics, metal content statistics, $\mathrm{pH}$ values of the leachates, $\mathrm{EC}$, and $\mathrm{Cd}, \mathrm{Pb}$, and $\mathrm{Zn}$ contents were analyzed using SPSS 12.0; Sigmaplot 10.0 was used to plot the graphs.

\section{Results}

3.1. Soil Characteristics. Table 3 shows the physicochemical characteristics and total metal contents of the soil used. The soil $\mathrm{pH}$ was 7.3, which is significantly higher than the reported value of 5.6 for farmlands in South Korea [19]. This may be due to the large quantity of crystalline limestone intercalated in the schist bedrock of the study area [20]. The contents of exchangeable calcium, magnesium, and potassium were 4.09 , 0.84 , and $0.37 \mathrm{cmol}^{+} / \mathrm{kg}$, respectively. Lee et al. [21] reported that the $\mathrm{pH}$ value of the soils surrounding the AMM sites in South Korea ranged between 5.2 and 7.0 (average $\mathrm{pH}$ 5.8), and the contents of exchangeable calcium, magnesium, and potassium ranged between 1.4 and 18.3, 0.3 and 9.4, and 0.02 and $1.3 \mathrm{cmol}^{+} / \mathrm{kg}$, respectively. The $\mathrm{Cd}, \mathrm{Pb}$, and $\mathrm{Zn}$ contents of the soil were $90.8 \mathrm{mg} / \mathrm{kg}, 8,058 \mathrm{mg} / \mathrm{kg}$, and $5,196 \mathrm{mg} / \mathrm{kg}$, respectively, which significantly exceed the national limit of soil quality [22].

The results of sequential extraction analysis on heavy metals for soil sample are shown in Table 4 . The acid 
TABLE 3: Physicochemical properties and total heavy metal content of the soil used in this study.

\begin{tabular}{lc}
\hline Parameter & Value $^{4}$ \\
\hline $\mathrm{pH}$ & $7.3 \pm 0.3$ \\
$\mathrm{Av} . \mathrm{P}_{2} \mathrm{O}_{5}(\mathrm{mg} / \mathrm{kg})^{1}$ & $546 \pm 35.8$ \\
Exch. cation $(\mathrm{cmol} / \mathrm{kg})^{2}$ & \\
$\quad \mathrm{Ca}^{2+}$ & $4.09 \pm 0.78$ \\
$\mathrm{Mg}^{2+}$ & $0.84 \pm 0.15$ \\
$\mathrm{~K}^{+}$ & $0.37 \pm 0.05$ \\
Soil texture (\%) & \\
$\quad$ Sand & \\
$\quad$ Silt & \\
$\quad$ Clay & \\
Metals (mg/kg) & \\
$\quad \mathrm{Cd}$ & $90.8 \pm 4.52$ \\
$\quad$ Pb & $8,058 \pm 105$ \\
$\quad$ Zn & $5,196 \pm 112$ \\
\hline${ }^{1}$ Available phosphate. \\
${ }^{2}$ Exchangeable cation. \\
${ }^{3}$ The total heavy metal content was digested via aqua regia according to the \\
standard method of soil pollution. The soil quality standards of Cd, Pb, and \\
Zn in South Korea are 4, 200, and 300 mg/kg, respectively. \\
${ }^{4}$ The figures are the averages and standard deviations of three replicates.
\end{tabular}

TABLE 4: Results of sequential extraction of $\mathrm{Cd}, \mathrm{Pb}$, and $\mathrm{Zn}$ in soil sampled.

\begin{tabular}{lccc}
\hline \multirow{2}{*}{ Fraction } & \multicolumn{3}{c}{ Heavy metal $(\mathrm{mg} / \mathrm{kg})$} \\
& $22.5(27.2 \%)^{\mathrm{e}}$ & $1,395(18.6 \%)^{\mathrm{e}}$ & $1,095(22.8 \%)^{\mathrm{e}}$ \\
$\mathrm{F}^{\mathrm{a}}$ & $6.56(7.95 \%)^{\mathrm{e}}$ & $548(7.30 \%)^{\mathrm{e}}$ & $292(6.06 \%)^{\mathrm{e}}$ \\
$\mathrm{F}^{\mathrm{b}}$ & $15.4(18.6 \%)^{\mathrm{e}}$ & $4,074(54.2 \%)^{\mathrm{e}}$ & $1,710(35.6 \%)^{\mathrm{e}}$ \\
$\mathrm{F}^{\mathrm{c}}$ & $38.1(46.2 \%)^{\mathrm{e}}$ & $1,495(19.9 \%)^{\mathrm{e}}$ & $1,713(35.6 \%)^{\mathrm{e}}$ \\
$\mathrm{F}^{\mathrm{d}}$ & &
\end{tabular}

${ }^{a}$ Acid soluble fraction (soluble and exchangeable fraction and bound to carbonates).

${ }^{\mathrm{b}}$ Reducible fraction (bound to Fe/Mn oxides).

${ }^{c}$ Oxidizable fraction (bound to organic matter and sulfides).

${ }^{\mathrm{d}}$ Residual fraction (aqua regia).

${ }^{\mathrm{e}}$ The values in parentheses are ratio of each extract to sum of each extraction.

soluble fractions of $\mathrm{Cd}, \mathrm{Pb}$, and $\mathrm{Zn}$ were $22.5 \mathrm{mg} / \mathrm{kg}(27.2 \%)$, $1,395 \mathrm{mg} / \mathrm{kg}(18.6 \%)$, and $1,095 \mathrm{mg} / \mathrm{kg}(22.8 \%)$, respectively.

3.2. The Change in the $p H$ and EC Values of the Leachate. Figure 2 shows the $\mathrm{pH}$ and EC (electrical conductivity) values of the leachate collected during the test period. The lowest $\mathrm{pH}$ was obtained from the leachate extracted from $1 \mathrm{PV}$ by applying the initial aqueous solution of $\mathrm{pH}$ 5.6. The $\mathrm{pH}$ of the limestone-treated soil column was 7.4 and was higher than that of the control column, which was 6.8. Thereafter, the $\mathrm{pH}$ value abruptly increased and remained constant. When the acid solutions of $\mathrm{pH} 4.8$ and $\mathrm{pH} 3.6$ were added to the top of the soil layer at $11 \mathrm{PV}$ and $21 \mathrm{PV}$, respectively, the $\mathrm{pH}$ values of leachates at $11 \mathrm{PV}$ and $21 \mathrm{PV}$ abruptly decreased, in a similar pattern to the early stage after the addition of the $\mathrm{pH} 5.6$ solution (Figure 2(a)). In particular, the $\mathrm{pH}$ values decreased most abruptly directly after the inflow of the $\mathrm{pH} 4.8$ solution (at $11 \mathrm{PV}$ ) and were the lowest since the inflow at $1 \mathrm{PV}$. In the control soil, the $\mathrm{pH}$ temporarily decreased in the early stages of augmentation but increased again and remained constant thereafter. This seems to be in response to the natural buffering capacity of the soil, which included a large quantity of limestone, as mentioned earlier [20]. The limestone-treated soil showed a similar tendency to the control soil, and the $\mathrm{pH}$ was similar to that of the control soil after $1 \mathrm{PV}$. The decrease in the $\mathrm{pH}$ values after the initial inflow of the solutions, however, was significantly smaller than that in the control soil.

The EC of the leachate had the opposite tendency to that of the $\mathrm{pH}$. The correlation between the $\mathrm{pH}$ and $\mathrm{EC}$ of the leachate was strongly negative $(r=-0.758$, with $P<0.01$ and $n=30)$. At $1 \mathrm{PV}$, which had the lowest $\mathrm{pH}$ value within the test period, the EC value was highest, but it abruptly decreased when the $\mathrm{pH} 5.6$ solution was added to the column (Figure 2(b)). In both the control and the limestone-treated soil columns, the EC abruptly increased at 11 and $21 \mathrm{PV}$, immediately after the inflow of the $\mathrm{pH} 4.8$ and $\mathrm{pH} 3.6$ solutions, respectively, and remained constant thereafter (Figure 2(b)).

The changes in the $\mathrm{pH}$ and $\mathrm{EC}$ values suggest that a large quantity of metal cations was initially leached after the inflow of acid solutions, when the $\mathrm{pH}$ decreased and the EC increased temporarily.

3.3. Leaching Concentrations of Heavy Metals in the Soil. During the column test, the change in metal concentrations was observed from collected leachates of the control and limestone-treated columns. In the control soil, the $\mathrm{Cd}$ concentration in leachate was $81.9 \mu \mathrm{g} / \mathrm{L}$ (the highest level during whole test period) at $1 \mathrm{PV}$, when the $\mathrm{pH} 5.6$ solution was first applied to the soil column (Figure 3(a)). This level was eight times greater than the national limit of groundwater quality $(10 \mu \mathrm{g} / \mathrm{L})$ [23]. The concentration at $2 \mathrm{PV}$ decreased to $25.6 \mu \mathrm{g} / \mathrm{L}$, two times greater than the national limit. Cd concentration abruptly decreased thereafter and remained constant at a value below the national limit. Cd concentration abruptly decreased thereafter and remained constant at a value below the national limit. Cd concentration sharply increased again in the early stages after the addition of the $\mathrm{pH}$ 4.8 and $\mathrm{pH} 3.6$ solutions. In particular, for the $\mathrm{pH} 4.8$ solution, the $\mathrm{Cd}$ concentration at $11,12,13$, and $14 \mathrm{PV}$ exceeded the national limit. These results suggest that should this kind of site experience acidic rainfall, metals could be released to the surrounding environment at the early stage of rainfall, even though the $\mathrm{pH}$ value of soil used was higher than the reported value ( $\mathrm{pH}$ 5.6) of farmland in South Korea [19].

In the column of limestone-treated soil, however, the $\mathrm{Cd}$ concentration was significantly lower than in the control soil and did not exceed the national limit. Moreover, it remained constant, unlike the case in the column of control soil, in which Cd was quickly leached during the early stages of the addition of an acid solution (Figure 3(a)). The total leached concentrations of $\mathrm{Cd}$ in the leachate were $8.40 \mu \mathrm{g} / \mathrm{L}$ in the control column and $0.52 \mu \mathrm{g} / \mathrm{L}$ in the limestone-treated column, which shows that the limestone treatment reduced the Cd concentration by approximately $94 \%$.

$\mathrm{Zn}$ had almost the same leaching characteristics as Cd (Figure 3(b)). In the control column, the $\mathrm{Zn}$ concentration 


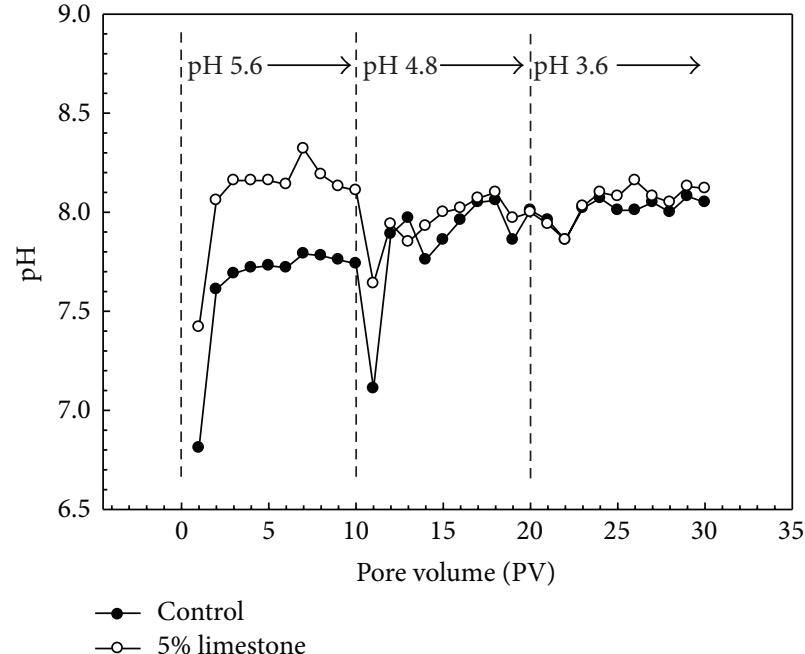

(a)

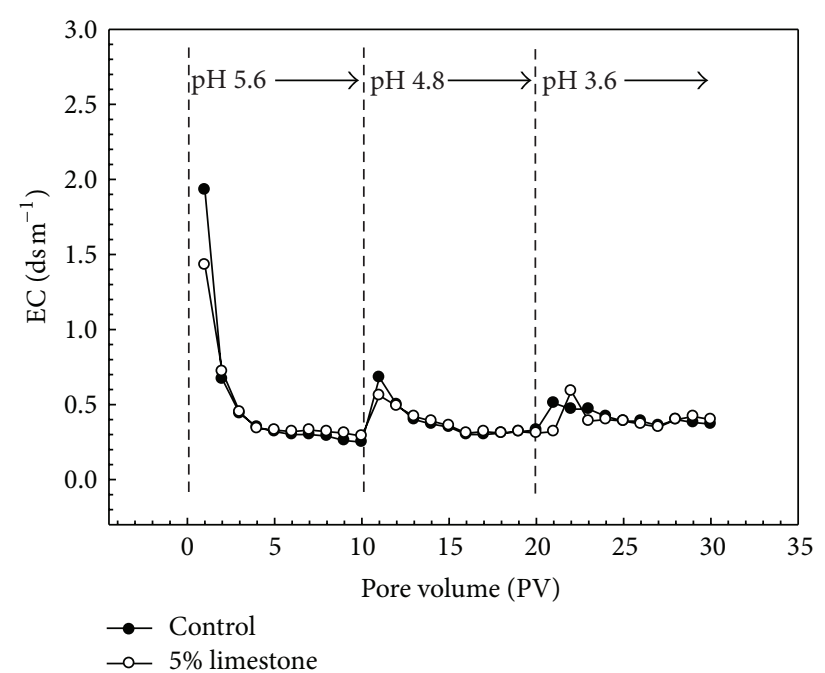

(b)

Figure 2: Variation of the (a) pH and (b) EC values of the leachates from the soil columns.

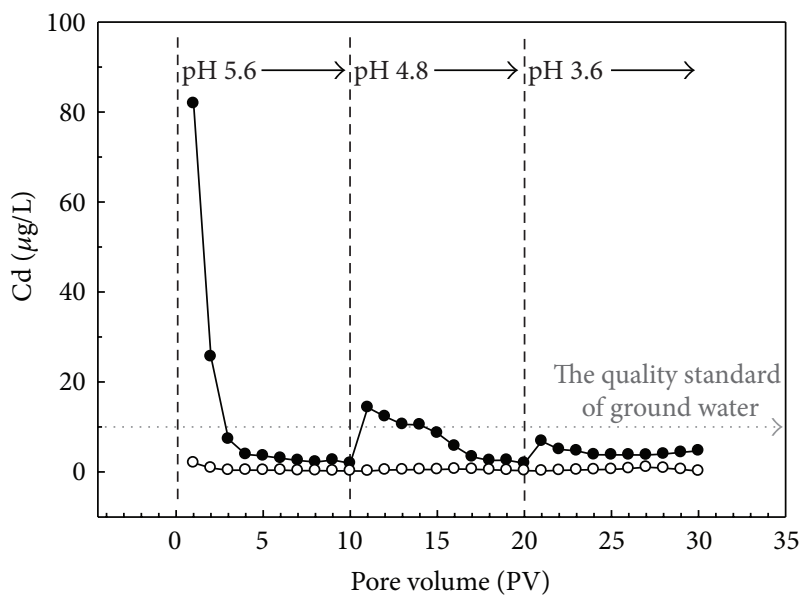

(a)

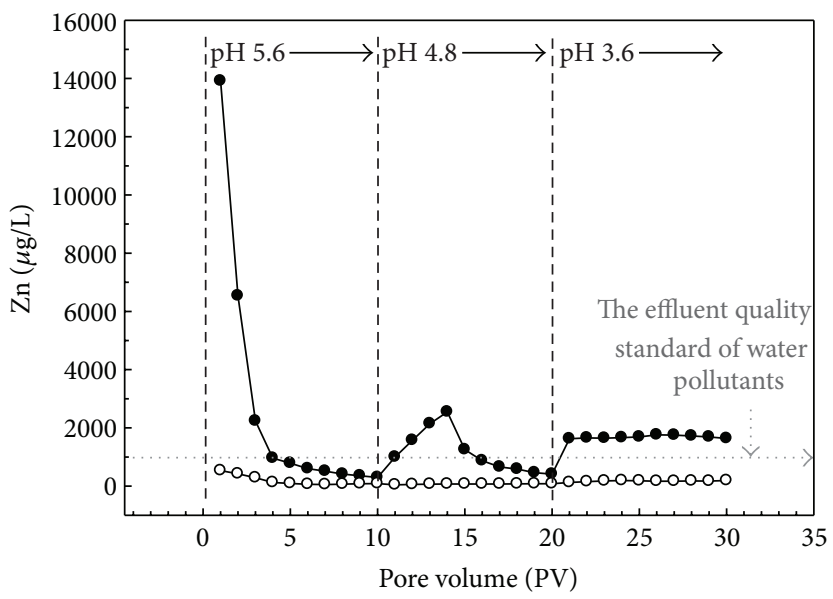

(b)

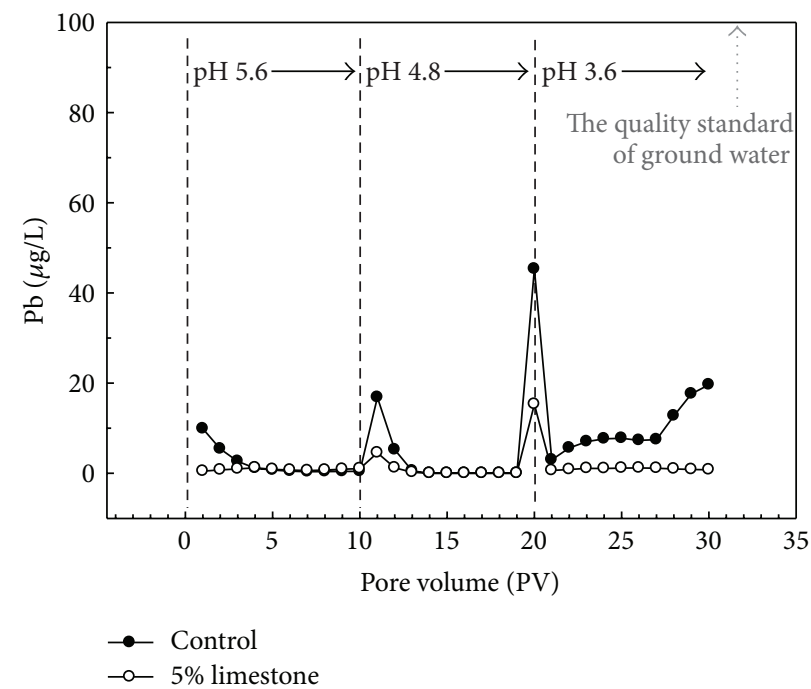

(c)

Figure 3: Variation of the heavy metal concentrations in the leachates from the soil columns ((a) Cd; (b) Zn; and (c) Pb). 
was $13,916 \mu \mathrm{g} / \mathrm{L}$ and was approximately 14 times greater than the national limit of effluent quality of surface water of $1,000 \mu \mathrm{g} / \mathrm{L}$. There is no national regulation of zinc in groundwater, so the surface water standards were used [23]. $\mathrm{Zn}$ concentrations from the control columns at 2 and $3 \mathrm{PV}$ were 6,536 and $2,238 \mu \mathrm{g} / \mathrm{L}$, respectively, which significantly exceeded the national limit. Thereafter, the $\mathrm{Zn}$ concentration continuously decreased to below the national limit. In the early stages of the addition of the $\mathrm{pH} 4.8$ and $\mathrm{pH} 3.6$ solutions, however, the $\mathrm{Zn}$ concentration abruptly increased again, in the same manner as for $\mathrm{Cd}$. However, the $\mathrm{Zn}$ concentration increased quickly between 11 and $14 \mathrm{PV}$, which corresponded to the early stages of the addition of the $\mathrm{pH} 4.8$ solution, and was maintained a little longer than $\mathrm{Cd}$. The $\mathrm{Zn}$ concentrations at 12, 13, and $14 \mathrm{PV}$ were 1,575, 2,144, and 2,548 $\mathrm{g} / \mathrm{L}$, respectively, which exceeded the national limit. At $21 \mathrm{PV}$, the addition of the $\mathrm{pH}=3.6$ solution, the $\mathrm{Zn}$ concentration abruptly increased to $1,627 \mu \mathrm{g} / \mathrm{L}$, which exceeded the national limit, and remained there for the rest of the test period.

In the limestone-treated column, the $\mathrm{Zn}$ concentration was significantly lower than that in the control column and remained below the national limit, without any obvious variation of leaching characteristics after the addition of acid solutions (Figure 3(b)). The total leached concentrations of $\mathrm{Zn}$ in the leachate were $1,832 \mu \mathrm{g} / \mathrm{L}$ in the control column and $141 \mu \mathrm{g} / \mathrm{L}$ in the limestone-treated column, which shows that the limestone treatment reduced the $\mathrm{Zn}$ concentration by approximately $92 \%$. These results verify the obvious effect of limestone treatment to reduce the $\mathrm{Zn}$ concentration of column effluents.

The $\mathrm{Pb}$ concentration in the leachate was $9.9 \mu \mathrm{g} / \mathrm{L}$ at $1 \mathrm{PV}$ and abruptly decreased thereafter. As the $\mathrm{pH} 5.6$ solution was being added, the $\mathrm{Pb}$ concentration remained constant at a level almost the same as that in the limestone-treated column (Figure 3(c)). At $11 \mathrm{PV}$, which corresponded to the addition of the $\mathrm{pH} 4.6$ solution, the $\mathrm{Pb}$ concentration abruptly increased to $16.8 \mu \mathrm{g} / \mathrm{L}$ and then decreased to a concentration similar to that in the limestone-treated column. At $20 \mathrm{PV}$, however, which was the final addition point of the $\mathrm{pH} 4.6$ solution, the $\mathrm{Pb}$ concentration was $45.3 \mu \mathrm{g} / \mathrm{L}$, the highest within the test period, and continued to increase as the $\mathrm{pH} 3.6$ solution seeped into the soil.

In the limestone-treated column, the $\mathrm{Pb}$ concentration also increased somewhat abruptly at 11 and 20 PV but was significantly lower than in the control column. Under the $\mathrm{pH} 3.6$ condition, the $\mathrm{Pb}$ concentration continued to increase in the control soil but remained constant at a significantly lower value (Figure 3(c)). The total leached concentrations of $\mathrm{Pb}$ in the leachate were $6.19 \mu \mathrm{g} / \mathrm{L}$ in the control column and $1.31 \mu \mathrm{g} / \mathrm{L}$ in the limestone-treated column, which showed that the limestone treatment reduced the $\mathrm{Pb}$ concentration by approximately $79 \%$.

\section{Discussion}

In the control column, $\mathrm{Cd}, \mathrm{Zn}$, and $\mathrm{Pb}$ were quickly leached during the early stages of the inflow of the acid solutions (Figure 3), and the leached $\mathrm{Cd}$ and $\mathrm{Zn}$ concentrations initially exceeded the groundwater quality limit and the surface water
TABLE 5: Pearson's correlation coefficients $r$ between $\mathrm{Cd}, \mathrm{Zn}, \mathrm{Pb}$, and $\mathrm{pH}$ in leachates of control column $(n=30)$.

\begin{tabular}{ccccc}
\hline & $\mathrm{pH}$ & $\mathrm{Cd}$ & $\mathrm{Zn}$ & $\mathrm{Pb}$ \\
\hline $\mathrm{pH}$ & 1 & $-0.769^{* *}$ & $-0.652^{* *}$ & 0.038 \\
$\mathrm{Cd}$ & $-0.769^{* *}$ & 1 & $0.965^{* *}$ & 0.060 \\
$\mathrm{Zn}$ & $-0.652^{* *}$ & $0.965^{* *}$ & 1 & 0.069 \\
$\mathrm{~Pb}$ & 0.038 & 0.060 & 0.069 & 1 \\
\hline
\end{tabular}

* Significant at $P<0.05$.

${ }^{* *}$ Highly significant at $P<0.01$.

standard, respectively, after the injection of the $\mathrm{pH} 5.6$ and $\mathrm{pH}$ 4.6 solutions. During the supply of the $\mathrm{pH} 3.6$ solution, the $\mathrm{Zn}$ concentration consistently exceeded the national limit of effluent quality of surface water in South Korea. The released $\mathrm{Pb}$ concentrations were relatively low, not exceeding the groundwater quality national limit of $100 \mu \mathrm{g} / \mathrm{L}$, but abruptly increased after the addition of the $\mathrm{pH} 4.6$ solution. The $\mathrm{Pb}$ concentration was highest at the final point of the addition of the $\mathrm{pH} 4.6$ solution. The $\mathrm{Pb}$ concentration continued to rise as the $\mathrm{pH} 3.6$ solution was added to the column.

The $\mathrm{pH}$ of the control column leachate initially decreased after the addition of the acid solutions (Figure 2), corresponding to the most abrupt increases in the $\mathrm{Cd}, \mathrm{Zn}$, and $\mathrm{Pb}$ concentrations (Figure 3 ). The correlation analysis of the $\mathrm{pH}$ and metal concentrations showed that $\mathrm{Cd}$ and $\mathrm{Zn}$ had a strongly negative correlation with $\mathrm{pH}$ (Table 5). As the soil contained a large quantity of limestone, its $\mathrm{pH}$ and acid buffering capacity were high, but its $\mathrm{pH}$ temporarily decreased directly after the addition of the acid solutions, leading to the abrupt leaching of its metal components.

The results of the column experiments described above showed that $\mathrm{Cd}, \mathrm{Zn}$, and $\mathrm{Pb}$ were also leached in the early stages of the experiment, after which their concentrations in the leachate continually decreased [24-29]. It is likely that the metals were present in highly soluble forms and immediately dissolved into the acid solutions and were leached [27]. Cd and $\mathrm{Zn}$ concentrations quickly increased after the inflow of the acid solutions and then quickly decreased. The $\mathrm{pH}$ of the leachate from the control column temporarily decreased directly after the supply of acid solutions and then abruptly increased due to the high alkalinity of the soil (Figure 2). An increase in $\mathrm{pH}$ enhances the negative charge on the soil, and the metal cations are adsorbed and precipitated onto the soil surface [14]. The affinity of metals for soil is enhanced more under neutral $\mathrm{pH}$ conditions than under acidic conditions because an increase in $\mathrm{pH}$ increases the electrostatic attraction of the materials adsorbed to the soil [30]. Therefore, it seems that $\mathrm{Cd}$ and $\mathrm{Zn}$ were quickly leached when the $\mathrm{pH}$ temporarily decreased, and then their concentrations in the leachate decreased as they were adsorbed or precipitated to the soil surface. It is expected, however, that the adsorbed and precipitated metals can easily be leached at any time with changes in rainfall and $\mathrm{pH}$.

Leaching trends of $\mathrm{Cd}$ and $\mathrm{Zn}$ in the control column showed a strong positive correlation (Figure 3 and Table 5). Chemically, $\mathrm{Cd}$ and $\mathrm{Zn}$ are very similar and are known to 
coexist in nature [31]. Cd and $\mathrm{Zn}$ within the control column, and the leachate of the present column test, displayed similar leaching trends. The leaching trends of $\mathrm{Pb}$, however, did not show any significant correlation with $\mathrm{Cd}$ and $\mathrm{Zn}$ and instead showed characteristics that were different from those of $\mathrm{Cd}$ and $\mathrm{Zn}$. Such correlation between $\mathrm{Cd}, \mathrm{Zn}$, and $\mathrm{Pb}$ in the leachate, or the leaching characteristic, was similar to the results described by Houben et al. [28].

The total $\mathrm{Cd}, \mathrm{Zn}$, and $\mathrm{Pb}$ contents were $90.8 \mathrm{mg} / \mathrm{kg}$, $5,196 \mathrm{mg} / \mathrm{kg}$, and $8,058 \mathrm{mg} / \mathrm{kg}$, respectively, in the soil used (Table 3 ). The total $\mathrm{Pb}$ content was highest by a wide margin and was approximately 88 times greater than that of Cd (Table 3 ). The total leached concentrations were the sum of the metal concentrations in the leachate collected over the test period divided by the number of leachates sampled $(n=30)$. The total leached concentrations of $\mathrm{Cd}, \mathrm{Zn}$, and $\mathrm{Pb}$ were 8.40, 1,832 , and $6.19 \mu \mathrm{g} / \mathrm{L}$, respectively, with the $\mathrm{Pb}$ concentration being by far the lowest. $\mathrm{Pb}$ is the most stable component of all metals found in soils [32-34], and Zhang and $\mathrm{Pu}$ [24] reported that $\mathrm{Pb}$ has the lowest mobility in nonacidic soils. The results of sequential extraction analyses on metals from soil samples are shown in Table 4 . The acid soluble fractions of $\mathrm{Cd}, \mathrm{Pb}$, and $\mathrm{Zn}$ were $22.5 \mathrm{mg} / \mathrm{kg}(27.2 \%), 1,395 \mathrm{mg} / \mathrm{kg}$ (18.6\%), and 1,095 mg/kg (22.8\%), respectively. Pb had a lower composition of weakly bound fractions than $\mathrm{did} \mathrm{Cd}$ and $\mathrm{Zn}$. The acid soluble fraction had the highest mobility and phytoavailability in soil. Kuo and Baker [35] and McLean and Bledsoe [36] suggest that $\mathrm{Pb}$ prevents the sorption of $\mathrm{Cu}$ and $\mathrm{Zn}$ in soil. $\mathrm{Cu}$ and $\mathrm{Zn}$ also prevent the sorption of $\mathrm{Cd}$. Therefore, $\mathrm{Pb}$ has the highest preferential adsorption in soils.

These characteristics of $\mathrm{Pb}$ in soil can be used to explain why $\mathrm{Pb}$ displayed different leaching characteristics than did $\mathrm{Cd}$ and $\mathrm{Zn}$. Moreover, these characteristics of $\mathrm{Pb}$ were more visible because of the high $\mathrm{pH}$ of the subject soil, which is due to the high content of limestone in the bedrock of the subject area.

The leached $\mathrm{Pb}$ concentration, however, was the highest at the final inflow point of the $\mathrm{pH} 4.8$ solution and continued to increase as the $\mathrm{pH} 3.6$ solution was being added to the soil. The concentration of $\mathrm{Pb}$ in the leachate collected during the observation period was below the national limit despite a high $\mathrm{Pb}$ content due to the characteristics of $\mathrm{Pb}$, which has relatively lower mobility than other metals in soil. However, the fact that the average $\mathrm{pH}$ of general Korean farmlands is slightly acidic at $\mathrm{pH}=5.6$ shows that $\mathrm{Pb}$ can be greatly leached at concentrations that can affect the surrounding environment due to $\mathrm{pH}$ changes, such as acid rain.

In the limestone-treated column, the decrease in $\mathrm{pH}$ was significantly smaller than that in the control column, and abrupt leaching of metals was almost never observed. Unlike the control column, in which metal concentrations significantly exceeded the national limit, metal concentrations were much lower than the national limit in the limestonetreated column. The main component of limestone, $\mathrm{CaCO}_{3}$, is a representative proton acceptor [37], and it seems that the increase in $\mathrm{CaCO}_{3}$ reduced $\mathrm{H}^{+}$and increased $\mathrm{OH}^{-}$ concentrations in the soil as the acid solutions passed through it, and the $\mathrm{pH}$ remained constant, even in the early stages of acid solution addition. Accordingly, it was believed that the leached metal concentrations decreased significantly because the acid buffering capacity of the soil was maintained.

\section{Conclusions}

This study examined the release of metals, especially Cd, $\mathrm{Zn}$, and $\mathrm{Pb}$, from contaminated soil treated by limestone, using a laboratory-scale column test with varying $\mathrm{pH} . \mathrm{pH}$ values were restricted to $3.6,4.8$, and 5.6. In this study, the $\mathrm{pH}$ of the subject soil was significantly high despite being from farrow land. This soil characteristic was not anticipated when this study was planned. Limestone was selected as the stabilization agent to reduce metal mobility by increasing soil $\mathrm{pH}$ because most Korean farmlands are slightly acidic. The characteristics of the treatment process of the stabilization method make determining an appropriate stabilization agent the most important task. If the $\mathrm{pH}$ of the soil in the reclamation target area is too high, the range of stabilization agents that can be selected narrows as generally alkaline material is not considered as a stabilization agent. However, this study generated some interesting results, which might provide basic data that can be considered when applying stabilization methods to contaminated soil with high $\mathrm{pH}$ for reclamation. Furthermore, highly alkaline soil can rapidly leach metal at high concentrations when rain or acidic rains temporarily reduce the acid buffering capacity of the soil. Slightly acidic soil was predicted to have noticeable effects on the mobility of metals and on the surrounding water systems induced by normal rain. Applying a stabilization agent such as limestone, however, was found to effectively reduce the leaching of metals by continuously maintaining the acid buffering capacity of the soil under conditions of altered $\mathrm{pH}$ such as acid rain. Moreover, despite the subject soil exhibiting a high $\mathrm{pH}$, limestone treatment did not increase the $\mathrm{pH}$ in a way that was disadvantageous to the soil environment.

\section{Conflict of Interests}

The authors declare that there is no conflict of interests regarding the publication of this paper.

\section{Acknowledgment}

The authors are thankful to the Korean Mine Reclamation Corp. (http://www.mireco.or.kr/), Seoul, Korea, for financial support.

\section{References}

[1] B.-Y. Park, J.-K. Lee, H.-M. Ro, and Y. H. Kim, "Effects of heavy metal contamination from an abandoned mine on nematode community structure as an indicator of soil ecosystem health," Applied Soil Ecology, vol. 51, no. 1, pp. 17-24, 2011.

[2] MIRECO, Yearbook of MIRECO Statistics 2009, Mine Reclamation Corporation, Seoul, Republic of Korea, 2010.

[3] Y. S. Ok, A. R. A. Usman, S. S. Lee et al., "Effects of rapeseed residue on lead and cadmium availability and uptake by rice plants in heavy metal contaminated paddy soil," Chemosphere, vol. 85, no. 4, pp. 677-682, 2011. 
[4] R. Khan, S. H. Israili, H. Ahmad, and A. Mohan, "Heavy metal pollution assessment in surface water bodies and its suitability for irrigation around the Neyevli lignite mines and associated industrial complex, Tamil Nadu, India," Mine Water and the Environment, vol. 24, no. 3, pp. 155-161, 2005.

[5] Y. M. Wang, T. C. Chen, K. J. Yeh, and M. F. Shue, "Stabilization of an elevated heavy metal contaminated site," Journal of Hazardous Materials, vol. 88, no. 1, pp. 63-74, 2001.

[6] A. Ruttens, K. Adriaensen, E. Meers et al., "Long-term sustainability of metal immobilization by soil amendments: cyclonic ashes versus lime addition," Environmental Pollution, vol. 158, no. 5, pp. 1428-1434, 2010.

[7] N. T. Basta and S. L. McGowen, "Evaluation of chemical immobilization treatments for reducing heavy metal transport in a smelter-contaminated soil," Environmental Pollution, vol. 127, no. 1, pp. 73-82, 2004.

[8] W. Hartley, R. Edwards, and N. W. Lepp, "Arsenic and heavy metal mobility in iron oxide-amended contaminated soils as evaluated by short-and long-term leaching tests," Environmental Pollution, vol. 131, no. 3, pp. 495-504, 2004.

[9] M. Malandrino, O. Abollino, S. Buoso, A. Giacomino, C. La Gioia, and E. Mentasti, "Accumulation of heavy metals from contaminated soil to plants and evaluation of soil remediation by vermiculite," Chemosphere, vol. 82, no. 2, pp. 169-178, 2011.

[10] J. Kumpiene, A. Lagerkvist, and C. Maurice, "Stabilization of As, $\mathrm{Cr}, \mathrm{Cu}, \mathrm{Pb}$ and $\mathrm{Zn}$ in soil using amendments-a review," Waste Management, vol. 28, no. 1, pp. 215-225, 2008.

[11] H. M. Conesa, Á. Faz, and R. Arnaldos, "Heavy metal accumulation and tolerance in plants from mine tailings of the semiarid Cartagena-La Unión mining district (SE Spain)," Science of the Total Environment, vol. 366, no. 1, pp. 1-11, 2006.

[12] Korea Ministry of Environment, Investigation of Soil Pollution Status Nearby Abandoned Metal Mine, Ministry of Environment, Gwacheon, Republic of Korea, 2007.

[13] Korea Ministry of Environment, Standard Methods of Soil Sampling and Analysis, Ministry of Environment, Gwacheon, Republic of Korea, 2009.

[14] C. Appel and L. Ma, "Concentration, pH, and surface charge effects on cadmium and lead sorption in three tropical soils," Journal of Environmental Quality, vol. 31, no. 2, pp. 581-589, 2002.

[15] Mine Reclamation Corporation (MIRECO), Monitoring on Heavy Metal Behavior in Remediated Area, Technology Series 2012-81, Mine Reclamation Corporation (MIRECO), Seoul, Republic of Korea, 2012, http://www.mireco.or.kr/jsp/bbs template/front/data06/download.csp?wid=NW03050101\&idx= 1358905353891.

[16] Korea Ministry of Environment, "Annual report of ambient air quality in Korea 2006," Tech. Rep., Korea Ministry of Environment, Gwacheon, Republic of Korea, 2007.

[17] NIST, Methods of Soil Chemical Analysis, National Institute of Agricultural Science and Technology, RDA, Suwon, Republic of Korea, 2000.

[18] Korea Ministry of Environment, Standard Methods of Water Sampling and Analysis, Ministry of Environment, Gwacheon, Republic of Korea, 2009.

[19] B. Jung, J. Choi, E. Yun, J. Yoon, and Y. Kim, "Monitoring on chemical properties of bench marked upland soils in Korea," Korean Journal of Soil Science and Fertilizer, vol. 34, no. 5, pp. 326-332, 2001.

[20] E. H. Hwang, A study on the heavy metal contamination of paddy soil in the vicinity of the Seosung Pb-Zn mine [M.S. thesis], Korea
National University of Education, Gangnae-Myeon, Republic of Korea, 2000.

[21] J.-M. Lee, W.-R. Go, A. Kunhikrishnan et al., "Model development for estimating total arsenic contents with chemical properties and extractable heavy metal contents in paddy soils," Korean Journal of Soil Science and Fertilizer, vol. 45, no. 6, pp. 920-924, 2012 (Korean).

[22] Korea Ministry of Environment, Soil Environment Conservation Act, Ministry of Environment, Gwacheon, Korea, 2010.

[23] Korea Ministry of Environment, Water Quality Conservation Act, Ministry of Environment, Gwacheon, Republic of Korea, 2010.

[24] M. Zhang and J. Pu, "Mineral materials as feasible amendments to stabilize heavy metals in polluted urban soils," Journal of Environmental Sciences, vol. 23, no. 4, pp. 607-615, 2011.

[25] P. Schwab, D. Zhu, and M. K. Banks, "Heavy metal leaching from mine tailings as affected by organic amendments," Bioresource Technology, vol. 98, no. 15, pp. 2935-2941, 2007.

[26] S. Hu, X. Chen, J. Shi, Y. Chen, and Q. Lin, "Particle-facilitated lead and arsenic transport in abandoned mine sites soil influenced by simulated acid rain," Chemosphere, vol. 71, no. 11, pp. 2091-2097, 2008.

[27] J. W. Jeon, B. H. Bae, and Y. H. Kim, "Applicability test of various stabilizers for heavy metals contaminated soil from smelter area," Korean Geo-Environmental Society, vol. 11, pp. 63$75,2010$.

[28] D. Houben, J. Pircar, and P. Sonnet, "Heavy metal immobilization by cost-effective amendments in a contaminated soil: effects on metal leaching and phytoavailability," Journal of Geochemical Exploration, vol. 123, pp. 87-94, 2012.

[29] P. Hu, B. Yang, C. Dong et al., "Assessment of EDTA heap leaching of an agricultural soil highly contaminated with heavy metals," Chemosphere, vol. 117, pp. 532-537, 2014.

[30] R. Naidu, R. S. Kookana, M. E. Sumner, R. D. Harter, and K. G. Tiller, "Cadmium sorption and transport in variable charge soils: a review," Journal of Environmental Quality, vol. 26, no. 3, pp. 602-617, 1997.

[31] K. W. Smilde, B. van Luit, and W. van Driel, "The extraction by soil and absorption by plants of applied zinc and cadmium," Plant and Soil, vol. 143, no. 2, pp. 233-238, 1992.

[32] M. Pueyo, J. Sastre, E. Hernandez, M. Vidal, J. López-Sánchez, and G. Rauret, "Prediction of trace element mobility in contaminated soils by sequential extraction," Journal of Environmental Quality, vol. 32, no. 6, pp. 2054-2066, 2003.

[33] L. Ramos, L. M. Hernandez, and M. J. Gonzalez, "Sequential fractionation of copper, lead, cadmium and zinc in soils from or near Donana National Park," Journal of Environmental Quality, vol. 23, no. 1, pp. 50-57, 1994.

[34] S. M. Ullrich, M. H. Ramsey, and E. Helios-Rybicka, "Total and exchangeable concentrations of heavy metals in soils near Bytom, an area of $\mathrm{Pb} / \mathrm{Zn}$ mining and smelting in Upper Silesia, Poland," Applied Geochemistry, vol. 14, no. 2, pp. 187-196, 1999.

[35] S. Kuo and A. S. Baker, "Sorption of copper, zinc, and cadmium by some acid soils," Soil Science Society of America Journal, vol. 44, no. 5, pp. 969-974, 1980.

[36] J. E. McLean and B. E. Bledsoe, "Behavior of metals in soils," in EPA Environmental Assessment Sourcebook, p. 19, 1996.

[37] A. Aiuppa, P. Bonfanti, and W. D’Alessandro, "Rainwater chemistry at Mt. Etna (Italy): natural and anthropogenic sources of major ions," Journal of Atmospheric Chemistry, vol. 46, no. 1, pp. 89-102, 2003. 

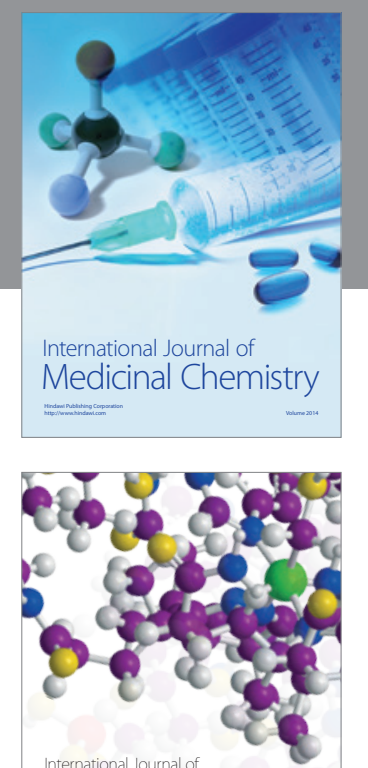

\section{Carbohydrate} Chemistry

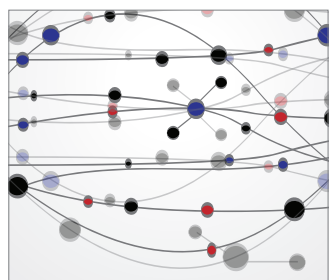

The Scientific World Journal
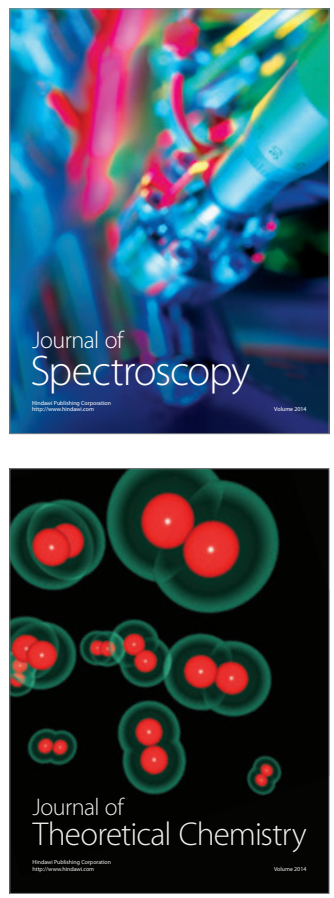
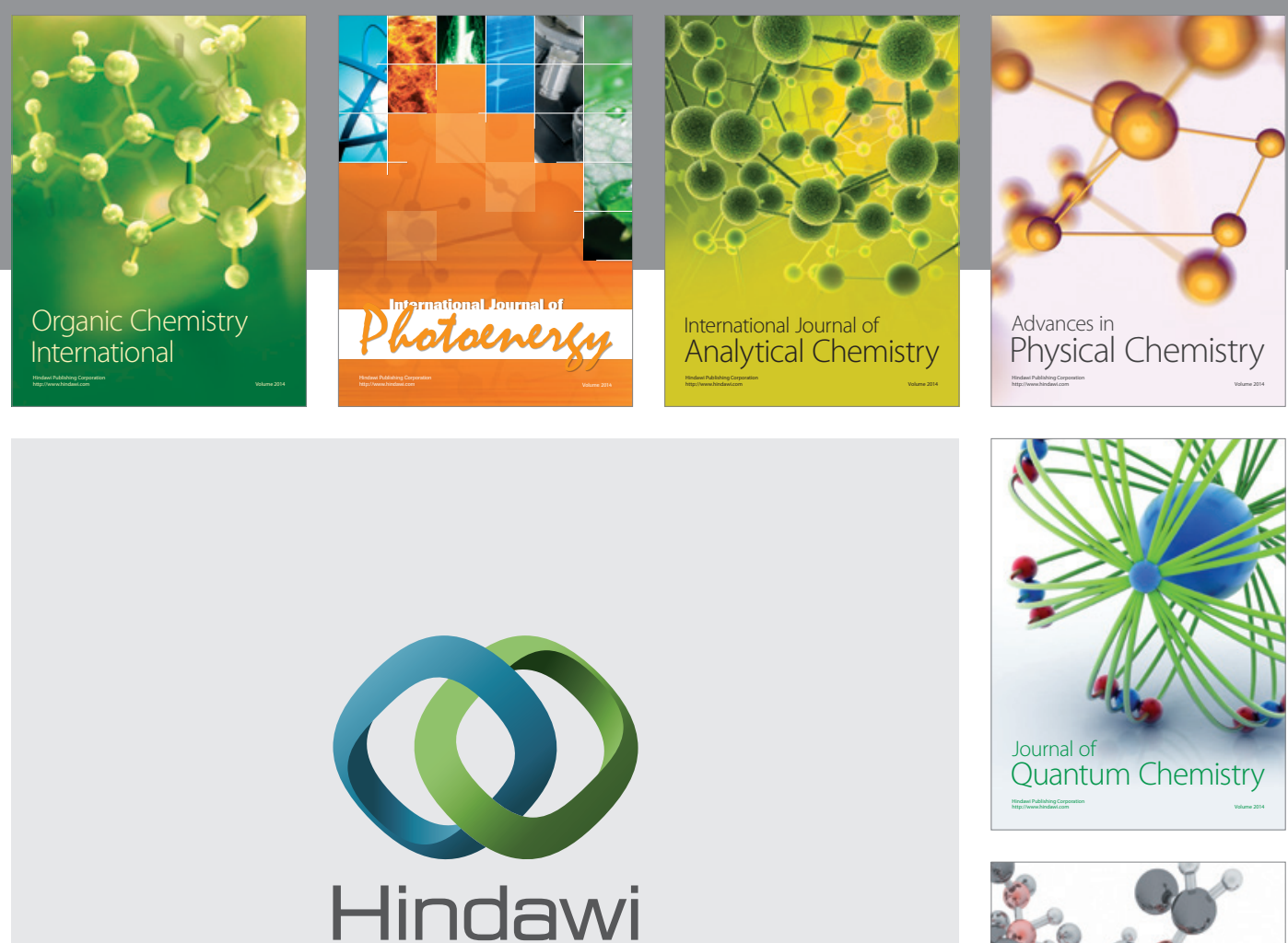

Submit your manuscripts at

http://www.hindawi.com

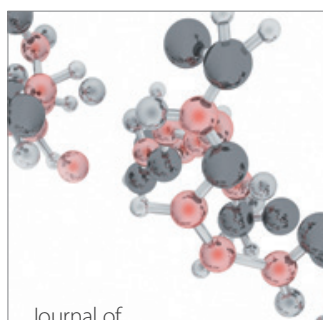

Analytical Methods

in Chemistry

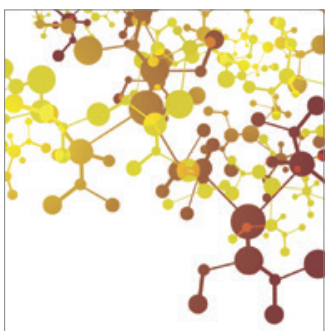

Journal of

Applied Chemistry

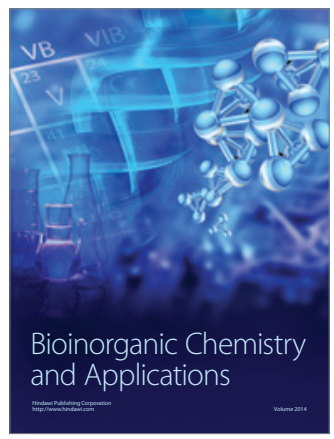

Inorganic Chemistry
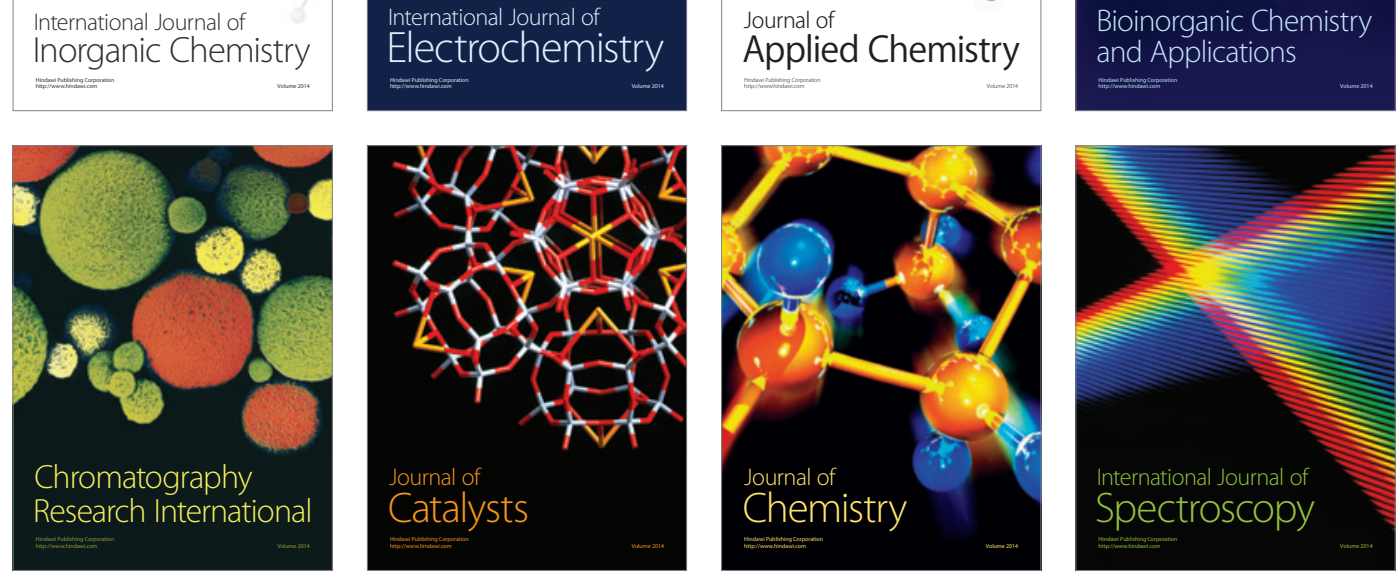